\title{
FACTORS ASSOCIATED WITH MOTIVATION OF EXCLUSIVE BREASTFEEDING
}

\author{
Sri Mulyani \\ Doctoral Program in Community Empowerement, Sebelas Maret University
}

\begin{abstract}
Background: In Indonesia coverage of exclusive breastfeeding was still as low as $29.5 \%$ in 2016 , which was far below the target set at $80 \%$. One of the factors affecting exclusive breastfeeding is motivation. The purpose of this study was to determine factors associated with motivation of exclusive breastfeeding.

Subjects and Method: This was a cross-sectional study conducted in Surakarta, Central Java. A sample of 150 postpartum mothers were selected for this study. The dependent variable was maternal motivation of providing exclusive breastfeeding. The independent variable were maternal knowledge, exposure to information, family support, and health personnel support. Data were collected by questionnaire and analyzed by multiple linear regression.

Results: Good motivation of providing exclusive breastfeeding was associated with bettter maternal knowledge $(b=0.23 ; \mathrm{p}=0.001)$, condusive culture $(b=0.29 ; p<0.001)$, exposure to information $(b=0.29 ; p<0.001)$, family support $(b=0.13 ; p=0.13)$, and health personnel support $(b=0.20 ; p=$ 0.001).

Conclusion: Good motivation of exclusive breastfeeding is associated with bettter knowledge, condusive culture, exposure to information, family support, and health personnel.
\end{abstract}

Keywords: exclusive breastfeeding, knowledge, family support, culture, exposure to information, health personnel

Correspondence: Sri Mulyani. Doctoral Program in Community Empowerement, Sebelas Maret University, Jl. Ir. Sutami 36A, Surakarta 57126, Central Java. Email: yaniartha@yahoo.com. Mobile: +6281225905095. 